\title{
Using fundamental, market and macroeconomic variables to predict financial distress: A study of companies listed on the Johannesburg Stock Exchange
}

\begin{tabular}{|c|c|}
\hline \multicolumn{2}{|c|}{$\begin{array}{l}\text { Authors: } \\
\text { Sibusiso W. Sabela }{ }^{1} \text { (D) } \\
\text { Leon M. Brummer }{ }^{1} \text { (D) } \\
\text { John H. Hall }{ }^{1} \text { (D) } \\
\text { Hendrik P. Wolmarans }{ }^{1} \text { (D) }\end{array}$} \\
\hline \multicolumn{2}{|c|}{$\begin{array}{l}\text { Affiliations: } \\
{ }^{1} \text { Department of Financial } \\
\text { Management, University of } \\
\text { Pretoria, South Africa }\end{array}$} \\
\hline \multicolumn{2}{|c|}{$\begin{array}{l}\text { Corresponding author: } \\
\text { Hendrik Wolmarans, } \\
\text { hendrik.wolmarans@up.ac.za }\end{array}$} \\
\hline \multicolumn{2}{|c|}{$\begin{array}{l}\text { Dates: } \\
\text { Received: } 22 \text { May } 2017 \\
\text { Accepted: } 29 \text { Nov. } 2017 \\
\text { Published: } 24 \text { Apr. } 2018\end{array}$} \\
\hline \multicolumn{2}{|c|}{$\begin{array}{l}\text { How to cite this article: } \\
\text { Sabela, S.W., Brummer, L.M., } \\
\text { Hall, J.H. \& Wolmarans, H.P., } \\
2018 \text {, 'Using fundamental, } \\
\text { market and macroeconomic } \\
\text { variables to predict financial } \\
\text { distress: A study of companies } \\
\text { listed on the Johannesburg } \\
\text { Stock Exchange', Journal } \\
\text { of Economic and Financial } \\
\text { Sciences } 11(1), \text { a168. } \\
\text { https://doi.org/10.4102/jef. } \\
\text { v11i1.168 }\end{array}$} \\
\hline \multicolumn{2}{|c|}{$\begin{array}{l}\text { Copyright: } \\
\text { C 2018. The Authors. } \\
\text { Licensee: AOSIS. This work } \\
\text { is licensed under the } \\
\text { Creative Commons } \\
\text { Attribution License. }\end{array}$} \\
\hline \multicolumn{2}{|l|}{ Read online: } \\
\hline 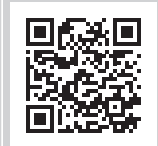 & $\begin{array}{l}\text { Scan this QR } \\
\text { code with your } \\
\text { smart phone or } \\
\text { mobile device } \\
\text { to read online. }\end{array}$ \\
\hline
\end{tabular}

This study presents a three-stage approach in determining financial distress of companies listed on the Johannesburg Stock Exchange. A novel feature of the present study is that it deviates from a binary classification of corporate distress prediction to present a multinomial outcome where the model predicts distressed, depressed and healthy companies. The research results show an improvement in the prediction accuracy rate when fundamental data is combined with market-based data. However, the further addition of macroeconomic indicators does not enhance the prediction accuracy.

\section{Introduction}

The need for reliable and rigorous corporate financial distress prediction models is of paramount importance, especially in today's world of financial uncertainty. Since the inception of statistical financial distress prediction models in the 1960s, there has been a constant improvement in methodologies and statistical techniques to accurately forecast corporate financial distress. The purpose of these models is to enhance the efficiency and stability of both the credit markets and the broader financial system, and also to warn company managers and shareholders of the possible impending danger of financial distress of the corporations in which they are stakeholders.

Government, shareholders, financiers, investors, credit rating agencies, auditors, suppliers, customers and employees are the immediately affected stakeholders of financial distress. The early detection of corporate financial distress is essential for the protection of various financial and social investments. For this reason, the prediction and classification of companies to determine whether they are potential candidates for financial distress has become a key topic of debate and research.

Financial distress prediction is a subject that is more than eight decades old. Fitzpatrick (1932) conducted the first research on this subject. At that time, there were no advanced statistical methods or techniques available to researchers. Often financial distress studies were based only on financial ratio comparisons, where the financial ratios of failed companies were found to be weaker than those in companies that had not failed. The two prominent innovators of statistical techniques for predicting financial distress were Beaver (1966) and Altman (1968) who, respectively, introduced univariate analysis and multidiscriminant analysis (also known as multiple discriminant analysis or MDA) for financial distress prediction.

As the existing literature is ambivalent regarding the value of fundamental data when predicting corporate financial distress, the aim of the present study is to add to the body of knowledge by adopting a three-stage approach in predicting corporate financial distress. This staggered approach seeks to test the financial distress prediction accuracy by using only fundamental financial data in the first stage, then by adding market data in the second stage to test for result enhancement and thirdly by adding macroeconomic variables in a final attempt to improve the financial distress prediction results.

As the objective of the present study is to increase the reliability of financial distress prediction methodology by conducting distress prediction in three stages with three levels of corresponding input variables, the research questions of the study are as follows:

1. Can the Stage 1 model (consisting of fundamental financial data only) accurately predict the financial distress of companies?

2. Does adding market-based variables improve the accuracy of financial distress prediction?

3. Does adding economic variables improve the accuracy of financial distress prediction? 
This study will make a number of contributions. Firstly, the approach of the present study to use three sets of inputs to try to enhance the accuracy of corporate financial distress prediction will add to the body of knowledge. Secondly, the present study adopted a multinomial model outcome instead of the commonly used binary outcome of 'failed' or 'not failed'. Thirdly, the results of the present study will provide investors, shareholders and corporate managers with a tool that will more accurately predict (and as a consequence then help to prevent) corporate financial distress. Lastly, the refinement of financial distress prediction is of the utmost importance to the providers of credit and capital. The accurate prediction of financial distress can help reduce and prevent financial losses for financial institutions.

The rest of the paper is structured as follows: The section 'Literature review' briefly discusses the literature of financial distress prediction. The section 'Research methodology' explains the research strategy adopted to ensure the research questions were addressed, the section 'Interpretation of results' presents the research results and the last section provides the conclusion.

\section{Literature review}

The literature review commences with a definition of financial distress, after which the evolvement of past financial distress models is addressed. This is followed by the statistical techniques applied to these models.

The terms financial distress, financial failure, unhealthy or sick and bankrupt have been used interchangeably in corporate financial literature. The literature shows a paradigm shift away from the pure legal definition to a more comprehensive definition that includes economic and accounting concepts (Manzaneque, Priego \& Merino 2016). For the purposes of the present study, financially 'distressed' companies are those companies that have been delisted or suspended from the Johannesburg Stock Exchange (JSE) because of financial failure. This study further defines financially 'depressed' companies as those that show negative movements in profitability on a year-on-year basis, as well as signs of technical insolvency.

Most researchers have tended to identify the lack of adequate liquidity and negative net cash flows as the triggers of financial distress. Carmichael (1978) stipulated four situations that should trigger financial distress, namely insufficiency of liquidity, insufficiency of equity, default of debt and the insufficiency of liquid capital. Doumpos and Zopounidis (1999) indicate that the mere inability to repay obligatory payments is not enough to be labelled as being in financial distress. Cao and Chen (2012) decided to use the movement of net cash flows to identify financial distress.

The literature shows a clear chronological development of financial models and statistical techniques for predicting corporate financial distress - from univariate analysis to the latest structural models. The groundbreaking work on models for financial distress prediction was conducted by Beaver (1966) when he developed a financial distress prediction model using fundamental financial data. He applied a univariate discriminant analysis based on various financial ratios selected by a dichotomous classification test. Beaver tested 14 ratios and found that the cash flow to total debt ratio was the best predictor of corporate bankruptcy (Beaver 1966). Tamari (1966) and Moses and Liao (1987) used risk index models to predict financial distress. These models are relatively simple and intuitive, using a point system based on different financial ratios.

With the intention of improving on Beaver's (1966) work on univariate analysis, Altman (1968) used a MDA model that consists of a linear combination of variables, which provides the best distinction between failing and non-failing firms. From the original list of 22 variables in Altman's (1968) study, only 5 financial ratios were found to possess a statistical discriminant power, namely:

working capital $\div$ total assets; retained earnings $\div$ total assets; earnings before interest and taxes $\div$ total assets; market value of equity $\div$ book value of total liabilities; and sales $\div$ total assets.

This model was more than $90 \%$ accurate in classifying bankrupt companies correctly one financial year prior to distress, and the model was more than $80 \%$ accurate in subsequent prediction tests. Altman, Haldeman and Narayanan (1977) introduced a revised version of Altman's original model, the zeta analysis. The authors justified the revision of the original Altman model on the basis of changes in accounting reporting standards since the 1960s. The resulting linear Zeta discriminant model is extremely accurate for financial distress prediction for up to 5 years before the actual occurrence of corporate financial distress. Recent research by Altman et al. (2016); Wang and Campbell (2010); and Chadha (2016) on financial distress prediction using Altman's Z-score provided favourable results for the model.

Dimitras, Zanakis and Zopounidis (1996) suggest that the use of MDAs has decreased since the 1980s. However, Altman et al. (2016) postulate that it remains a generally accepted standard method and that it is frequently used as a baseline method for comparative studies. Multiple discriminant analysis has been replaced by relatively less demanding statistical techniques, such as logistic analysis, probit analysis and linear probability modelling.

Logistic analysis, probit analysis and linear probability modelling methods resulted in conditional probability models. Such models consist of a combination of variables that distinguish failing from non-failing firms (Doumpos \& Zopounidis 1999; Zavgren 1983; 1985). Ohlson (1980) pioneered the use of logistic analysis in company financial distress prediction, whereas Zmijewski (1984) was the first to use probit analysis. Until the 1980s logistic analysis was a popular method for identifying business distress prediction. 
The number of studies that used probit analysis compared to other methods was however relatively small, probably because the probit technique requires more computations (Dimitras et al. 1996; Gloubos \& Grammatikos 1988).

Hand and Henley (1997) suggest that logistic analysis is a more appropriate instrument for financial distress prediction than linear regression, because logistic analysis allows for the definition of two distinct classes of outcomes. The logistic analysis model combines several of the firm's characteristics or attributes into a multivariate probability score, which indicates the firm's financial distress probability or vulnerability to financial distress. The logistic analysis model allows for categorical qualitative variables (Keasey \& Watson 1987). Among other researchers, Ahmadi et al. (2012) also used the logit model with success.

Muller, Steyn-Bruwer and Hamman (2009) compared techniques for the prediction of financial distress of companies listed on the JSE. Other researchers who focused on JSE-listed companies include Holtzhausen (2011), Cassim (2015), Van der Colff and Vermaak (2015) and Rowlings (2016).

Neural network models were introduced in financial distress prediction studies in the 1990s (Odom \& Sharda 1990; Tam \& Kiang 1992). The level of accuracy and performance of this technique was evaluated against the then-popular statistical technique (logistic analysis) and the results indicated that neural network methods provide superior results to those obtained from the logistic analysis method (Yim \& Mitchell 2005). Aydin and Cavdar (2015) postulated that neural network models are powerful tools for enhancing financial modelling flexibility and dynamism and that they can be used to successfully predict a financial crisis.

In a more recent study Shah (2014) investigated five techniques for predicting corporate financial distress, namely logistic analysis, MDAs, neural networks, as well as two hybrid models. Regarding the hybrid models, Shah (2014) first combined logistic analysis and artificial neural networks and labelled the model 'Hybrid I'. Thereafter, a second hybrid model was constructed combining MDAs and artificial neural networks. This model was labelled 'Hybrid II'. Table 1 depicts the results of his comprehensive study.

Table 1 shows the advantage of using neural networks over classic statistical methodologies for predicting corporate financial distress. As subsequently confirmed by Aydin and

TABLE 1: The accuracy results of five different techniques for predicting financial distress.

\begin{tabular}{lc}
\hline Model & Prediction accuracy (\%) \\
\hline Hybrid I - artificial neural network and logistic analysis & 94.0 \\
Artificial neural network & 93.7 \\
Logistic analysis & 91.9 \\
Hybrid II - artificial neural network and multiple & 91.0 \\
discriminant analysis & 82.8 \\
\hline Multiple discriminant analysis & \\
\hline
\end{tabular}

Source: Shah, N., 2014, 'Developing financial distress prediction models using cutting edge Source: Shah, N., 2014, 'Developing financial distress prediction models using cutting edge
recursive partitioning techniques: A study of Australian mining performance', Review of Integrative Business and Economics Research 3(2), 103-143
Cavdar (2015) neural networks are flexible and dynamic compared to the rules, restrictions and assumptions that form the basis of other statistical models (Ala'raj \& Abbod 2016; Cleofas-Sanchez et al. 2016). MDA is the most restrictive statistical technique compared to the other models in Table 1 . This may explain why MDA was the worst-performing technique in predicting corporate financial distress in Shah's (2014) study. It is outside the scope of the present study to discuss the advantages and disadvantages of neural networks, but an excellent exposition is given by López Iturriaga and Sanz (2015), where they highlight some of the salient features of expert systems compared to other empirical approaches used for corporate financial distress prediction.

In conclusion, the corporate financial distress prediction models used in past research were based predominantly on analysing company-specific fundamental data. The literature review shows a propensity by some researchers to move away from fundamental data to market data analysis for predicting corporate financial distress. There is also limited evidence of studies that have used macroeconomic data in predicting distress. Therefore, the present study employed a three-stage process, where three sets of variables (fundamental data, market data and macroeconomic variables) were used to test for their significance in predicting corporate financial distress. The next section describes the research methodology.

\section{Research methodology}

The objectives of this section are to discuss the sampling and data collection strategy, to define the independent and dependent variables that were used in the study, to discuss the selected statistical technique in developing the model and lastly to discuss the data analysis.

The sample consisted of JSE-listed firms that were listed from 31 December 2005 to 31 December 2014. The INET BFA (now IRESS, a South African supplier of quality financial data) database was used to source the equity prices, equity volatilities, market capitalisation and company debt levels. The South African Reserve Bank's website was used to source the 90-day treasury bill rate for the period covered in this study.

A stratified random sampling technique was adopted in selecting the companies. Two groups of companies were selected at the initial stage: a group of JSE-listed companies and a group of delisted companies. The next process was to clean up the data by applying an elimination process on the population of companies to derive the final list of companies used for the empirical analysis. Companies were eliminated if they changed their financial year, main line of business or if there were no consecutive financial statements (because of a change of financial year end). In addition, financial institutions were not considered because of the fact that their debt-equity ratios are not fully comparable to other companies. Among the group of delisted companies only the companies that were delisted because of financial failure 
were selected as part of this group. This was to avoid selecting companies that were delisted either voluntarily or for other business reasons.

The above elimination process resulted in a set of listed and delisted companies. The delisted companies were categorised as financially distressed. The next process was to categorise the group of listed companies as either healthy or depressed. In defining financially depressed companies, the study considered the year-on-year movement in earnings before interest and tax, plus income from associated companies; and secondly current assets in relation to current liabilities, during the last 5 years of the study. The companies that showed year-on-year positive movements in one or both of the parameters for the total of the 5-year period under review were categorised as healthy. Similarly, the companies showing negative (or declining) movements, for 3 sequential years in the 5-year period under review, in any one of these two parameters, were categorised as depressed.

Based on the two sets of parameters the final sample consisted of 100 companies categorised as follows: 78 as healthy, 14 as depressed and 8 as distressed. The approach adopted in this study regarding the percentage composition of distressed companies is in line with existing literature. For example, Ohlson's (1980) study consisted of 5\% failed companies. It is also in line with more contemporary studies, such as Åstebro and Winter (2012), who had a 12\% representation of failed companies, and Tinoco and Wilson (2013), who had a 13\% representation of failed companies. Therefore, with $8 \%$ of distressed companies, the sample of the present study is in line with extant research.

The companies in the final sample represent various economic sectors, but the dominance of industrial companies cannot be ignored. The industrial sector represents $37 \%$ of the total sample population. This is followed by the retail sector constituting $19 \%$ of the population. The other economic sectors represented include: chemicals at $6 \%$, food and beverages at $10 \%$, healthcare sector at $3 \%$, media at $3 \%$, personal and households at 3\%, technology at 9\%, travel and leisure at $9 \%$ and telecoms at $2 \%$.

\section{Independent and dependent variables}

This study aimed to predict corporate financial distress using a three-stage approach. These stages were based on three types of inputs, namely fundamental financial ratios, marketbased variables and macroeconomic variables. The literature review revealed a large number of ratios available for researchers to use when determining a company's financial distress. However, using all of the available ratios could inadvertently lead to incorrect research conclusions. It would also be impractical and time-consuming, without providing significant results in financial distress prediction.

In the financial distress prediction literature, the selection of financial ratios was based on a ratio's successful performance in previous studies. The ratio selection was also often based on the popularity of specific ratios. Once the financial ratios were selected they were categorised according to their respective attributes, namely solvency, profitability, operational capabilities, business development capacity, structural soundness and capital expansion capacity. Some ratios contained similar elements and thus introduced problems of spuriousness into data analyses. Consequently, these ratios were tested for collinearity and significantly correlated ratios were eliminated.

Bellovary, Giacomino and Akers (2007) reviewed 165 financial distress prediction studies. After scanning 752 different ratios in different studies, they found that the number of ratios considered in any one study ranged from 1 to 57 . The most common ratio in multiple studies was the ratio of net income to total assets (return on assets), which was used in 54 studies. The second most common ratio was the ratio of current assets to current liabilities (current ratio), which was found in 51 studies. Six studies used the five variables included in Altman's (1968) original multivariate model.

In line with previous research a total of 35 ratios were selected for the present study. The ratios were based on their popularity and performance in previous studies. The list of ratios consisted of fundamental data (25), market ratios (5) and macroeconomic variables (5). These ratios were then subjected to multicollinearity tests, after which a final list of 10 variables for use in the empirical analysis of the present study emerged, namely five fundamental accounting ratios, three market ratios and two macroeconomic indicators. The fundamental ratios used in the study were as follows: working capital over total assets (WCTA), total debt $\div$ total assets (TDTA), earnings before interest and tax $\div$ total assets (EBITTA), turnover $\div$ total assets (TOTA), and market capitalisation $\div$ total debt (METD). The final market-based ratios were price per earnings $(\mathrm{P} / \mathrm{E})$, price per share $(\mathrm{P} / \mathrm{S})$ and price per cash flow (PCF). The macroeconomic variables were gross domestic product (GDP) and the unemployment rate (UR).

This study adopted three possible outcomes (categories) for predicting financial distress in the JSE-listed companies. The first outcome was to classify distressed companies; the second outcome was to classify depressed companies and the last outcome concerned the classifying of healthy companies. The present study thus envisaged a multinomial model outcome instead of the commonly used binary outcome of failed or not failed.

Figure 1 indicates that the financial position of a company is always in a state of flux influenced by prevailing (internal or external) economic variables. The chart contains three zones, namely a green zone, an orange zone and a red zone. Companies in the red zone are identified as distressed, companies in the green zone are companies that are still listed on the JSE and are assumed to be in a healthy financial condition. The most important state is the orange, or 


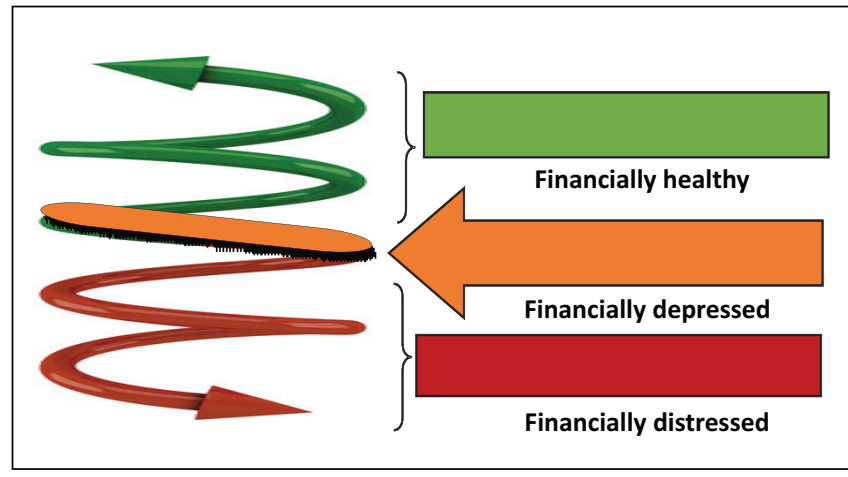

FIGURE 1: A spiral curve reflecting the three financial states.

financially depressed, state. In this state the company's financial results are sending warning signals to management for immediate intervention. Failure to react promptly may lead the company into the red zone.

The multinomial financial distress outcome is preferred because decision makers want to know well in advance whether a company may become financially distressed. The decision makers would receive an early and noisy warning signal that a company is facing financial distress.

\section{Statistical model}

The literature review above detailed the strengths and weaknesses of different statistical techniques, which led the present study to choose logistic analysis as the research model. The selection was based mainly on the popularity of the logistic analysis model and its seemingly relaxed statistical assumptions compared to MDAs. The outcome variable in logistic analysis is either binary or multinomial.

The technique of logistic regression and its use of logit (log odds) was described by Bennett (1983) and Peng, Lee and Ingersoll (2002). Studies that successfully applied this technique in financial distress prediction include those by Ohlson (1980), Zavgren (1983), Lussier (1995), Laitinen and Laitinen (2000), Tseng and Lin (2005), Jones and Hensher (2007) and Li and Sun (2011).

The probability of the outcome is measured by the odds of occurrence of an event. If $(\mathrm{P})$ is the probability of an event, then $(1-\mathrm{P})$ is the probability of it not occurring. The odds of success are therefore $=\mathrm{P} / 1-\mathrm{P}$.

The joint effect of all explanatory variables put together on the odds is:

Odds $=\mathrm{P} / 1-\mathrm{P}=e^{\alpha+\beta_{1 X 1}+\beta_{2 X 2}+\ldots+\beta_{P X P}}$

Taking the logarithms of both sides:

$\log \{\mathrm{P} / 1-\mathrm{P}\}=\log ^{\alpha+\beta_{1 X 1}+\beta_{2 X 2}+\ldots+\beta_{P X P}}$

Logit $\mathrm{P}=\alpha+\beta_{1} X_{1}+\beta_{2} X_{2}+\ldots+\beta P X P$

[Eqn 3]
The coefficients $\beta_{1^{\prime}} \beta_{2^{\prime}} \beta_{\mathrm{p}}$ are such that the sums of the squared distance between the observed and predicted values (regression line) are smallest.

Logit $\mathrm{p}=\alpha+\beta_{1} \mathrm{X}_{1}+\beta_{2} \mathrm{X}_{2}+\ldots+\beta_{\mathrm{p}} \mathrm{XP}$

[Eqn 4]

Where:

$\alpha$ represents the overall risk.

$\beta_{1}$ represents the fraction by which the distress risk is altered by a unit change in $X_{1}$.

$\beta_{2}$ is the fraction by which the distress risk is altered by a unit change in $X_{2}$, and so on. The odds themselves are changed by $e^{\beta}$.

If $\beta=1.6$, the odds are $e^{1.6}=4.95$.

As discussed above, in applying logistic analysis this study defined three possible outcomes: healthy $=2$, depressed $=1$ and distressed $=0$. The present study used multinomial logistic analysis and not binomial analysis.

The statistical analysis was based on a panel data set that consisted of data sourced from the annual financial statements of a sample of JSE-listed companies for the period of 2005-2014. The sample covered different business sectors and all company sizes, namely small, medium and large. Tests for outliers, missing data and data transformation were conducted and corrected where applicable.

The influence of outliers can be severe in regression analysis and may lead to incorrect inferences. Therefore, this test is conducted to mitigate that risk in trimming all variables that are identified as outliers. Outliers are inherently experienced in studies of financial distress as the sampled population would consist of companies from different economic sectors and of different sizes both economically and financially.

Another compelling reason to test for outliers is to doublecheck the accuracy and integrity of the data set and the running of experiments. In cases where data is found to be coded incorrectly or the statistical program may not have been run correctly, then the outlying point may be erroneous. In this case, the outlying value is deleted from the analysis or corrected if possible. Statistical software was used to identify extreme values in the data. Once these values are identified, a winsorising technique was applied to adjust the data.

\section{Analysis of results using the three-stage model}

In this section the results of the analysis by way of the threestage model are given in Tables 2 through 4 . The three-stage model involves the systematic addition of independent variables to the model with the aim of improving the prediction accuracy of the model. Stage 1 was the analysis of prediction results based on fundamental data. In Stage 2 
market-based ratios were added. Finally, in Stage 3 macroeconomic variables were added.

The purpose of this systematic combination of ratios was to test whether each set of variables possessed any additional predictive power. Should the prediction results improve as a direct consequence of adding the new set of variables, it could be inferred that the added set of variables contained additional predictive power. The analysis covered five periods $-5,4,3,2$ and 1 years before distress. The period spread aimed to detect the predictive power of the variables as the number of years to distress decreased. Table 2 displays the number of companies used in the study, categorised according to their financial status.

As can be seen in Table 2 the data contains 100 cases, comprised of a combination of distressed, depressed and healthy companies. In previous dichotomous studies, the number of companies was sometimes equal for each group of failed and not-failed companies, but this was not the case in this study.

The selection of the 100 companies was preceded by a systematic and staggered approach to eliminate companies that are not relevant for this study. It is by mere coincidence that the final sample is a rounded number of 100 .

Of the 100 companies, 92 were listed on the JSE while the other 8 were companies that were delisted because of financial distress. Therefore, in line with the study methodology, the list of delisted companies was treated in this study as the list of financially distressed companies. The study recognises three financial states: distressed, depressed and healthy. Hence, a criterion was set to identify any company that may be financially depressed among the 92 companies that were still listed.

Two parameters were used in identifying depressed companies: companies with three or more consecutive annual decreases in earnings before interest and tax, plus income from associated companies during the latest 5 years, as well as 3 subsequent years of negative net working capital during the latest 5 years, were defined as depressed. After applying the criterion, 14 companies were identified as depressed, while 78 companies were defined as healthy.

The approach adopted in the present study regarding the percentage composition of companies is in line with one of many classical papers authored by Ohlson (1980:107), whose study consisted of $5 \%$ failed companies. It is also in line with more contemporary studies, like those of Åstebro and Winter (2012:1), who had a 12\% representation of failed companies, and

TABLE 2: The number of companies used in the study.

\begin{tabular}{lcc}
\hline Status of companies & $\boldsymbol{N}$ & Percentage \\
\hline Distressed & 8 & 8 \\
Depressed & 14 & 14 \\
Healthy & 78 & 78 \\
\hline Total & - & $\mathbf{1 0 0}$ \\
\hline
\end{tabular}

Tinoco and Wilson (2013:394), who had a 12.6\% representation of failed companies. Therefore, at $8 \%$ of distressed companies, the present study is in line with extant research.

\section{Model goodness of fit: Total model}

The model goodness of fit (see Table 3) serves to provide a level of satisfaction concerning the integrity of the model or model performance. The logistic analysis model works differently to the simple regression model (ordinary least squares analysis), where $R$-square values play a pivotal part in explaining the model performance. The logistic analysis model applies the maximum likelihood of the odds as an indicator of model performance. While $R$-square is used as a model performance indicator for simple regression models, in the logistic analysis model pseudo $R$-square is a similar indicator, as used by Ohlson (1980) and Zavgren (1985). Logistic analysis is estimated by maximising the likelihood function. For instance, let $L_{0}$ be the value of the likelihood function for a model with no predictors, and let $L_{M}$ be the likelihood for the model being estimated. The pseudo $R$-square or McFadden's $R^{2}$ is then defined as:

$R^{2} \mathrm{~m} c f=1-\ln \left(L_{M}\right) / \ln \left(L_{0}\right)$

[Eqn 5]

where $\ln ($.$) is the natural logarithm (McFadden 1974). The$ rationale for this formula is that $\ln \left(L_{0}\right)$ plays a role analogous to the residual sum of squares in linear regression. Consequently, this formula corresponds to a proportional reduction in 'error variance'.

The pseudo $R$-square percentage explains approximately how much variation in the outcome is explained by the model. This further suggests that the model performed satisfactorily, showing a strong relationship between independent variables and dependent variables.

With regard to the $-2 \log$ likelihood (measure -2LL), the first line shows the intercept only figures. This communicates an intercept where all independent variables are held at zero. The second line shows the final figures that represent the impact or the movement as a result of adding the variables to the model. This therefore provides satisfaction that the independent variables impact the model responsive variables. Furthermore, the level of chi-square and its significance level, where the alpha is set at 0.05 , are additional indicators that provide confidence in the performance of the model. The achieved significance levels are all below 5\%, which confirms that predictor variables have a significant impact on the outcome variables.

TABLE 3: The performance of the overall model measured in goodness of fit and pseudo $R$-square.

\begin{tabular}{llccccc}
\hline Variable & Statistic & \multicolumn{5}{c}{ Years before financial distress } \\
\cline { 3 - 7 } & & Five & Four & Three & Two & One \\
\hline Pseudo $R^{2}$ & McFadden & $34 \%$ & $52 \%$ & $29 \%$ & $28 \%$ & $42 \%$ \\
-2 LL & Intercept only & 134.22 & 134.22 & 134.22 & 134.22 & 134.22 \\
& Final & 88.95 & 64.39 & 95.02 & 96.46 & 78.12 \\
& Chi-square & 45.27 & 69.83 & 39.20 & 37.77 & 56.10 \\
& Significance & 0.000 & 0.000 & 0.000 & 0.000 & 0.000 \\
\hline
\end{tabular}




\section{Prediction accuracy rate: Stage 1 and stage 2 models}

Table 4, Panel A shows the percentages per financial state based on the number of years before financial distress. This reflects the financial distress prediction accuracy based on the multinomial logistic regression analysis applied to only fundamental data.

The percentage prediction accuracy as per Table 4 was calculated by statistically comparing the model prediction (for both Stages 1 and 2 models) of all 100 companies as depressed, distressed or healthy, with that of the company classification as defined in the 'Interpretation of results' section (see Table 2). If the company classification and prediction were, therefore, exactly the same for a specific year, the percentage prediction accuracy would be $100 \%$.

Table 4, Panel A, shows, for example, a 63\% correct prediction accuracy rate for distressed companies 1 year before financial distress, a $7 \%$ prediction accuracy for depressed companies and a 100\% prediction accuracy for healthy companies. This gives an overall prediction accuracy percentage of $84 \% 1$ year before financial distress. The model appears to have better predictive power in Years 4 and 5 before financial distress. This is contrary to the more common findings of the literature, which suggest that prediction accuracy deteriorates the more years away the company is from actual financial distress.

Table 4, Panel B, provides the percentage predictive accuracy when market-based data was added to the model. The Stage 2 model consistently and accurately predicted $100 \%$ of the companies that were financially distressed for all the years before failure.

The Stage 2 model also showed an improvement from the Stage 1 model. However, there was a similar trend in both models, in that the prediction accuracy in Year 4 was better than that of Year 1 before financial distress. This model shows nearly $100 \%$ prediction accuracy for both distressed and healthy companies - a prediction that is consistent for all the years before financial distress. It may thus be concluded that the addition of market-based variables positively improved the prediction accuracy results. For example, the average accuracy for the 5 years in the Stage 2 model was 88\%, whereas for the Stage 1 model it was only $85 \%$.

For the Stage 3 model economic data was added to the model. However, and somewhat disappointingly, there was no improvement in predictive accuracy from that of the Stage 2 model. There was thus no improvement as a result of adding macroeconomic variables.

In conclusion, a model based on fundamental data was able to predict financial distress with an acceptable level of accuracy reaching a high of $88 \%$ in Year 4 before distress. The addition of market-based data further enhanced the prediction accuracy, by increasing the prediction accuracy percentage to $90 \%$ in Year 4 before financial distress. It is also clear that adding macroeconomic variables did not add significant improvement in predictive power.

\section{Determination of a cut-off point and calculation of type I and type II errors in validating the model}

Because of the fact that the accuracy prediction rate for Years 4 and 5 was higher than that of Year 1, and that the models were failing in the prediction of the depressed companies (both in contradiction to previous research), it was necessary to also calculate the Types I and II errors in validating the models.

As a mechanism of validating the model, it is important to determine the cost of error in the model. The model in the present study seeks to predict the financial state of companies; therefore the model is expected to identify and group companies that are distressed, depressed and healthy. The model results presented in this study prove that the model is capable of making the classification at an acceptable level. However, it would be wrong to ignore the cost of errors the model has made. The cost of errors is introduced when the model identifies a distressed company as healthy, or when the model identifies a healthy company as distressed. These errors are referred to as Types I and II errors.

A Type I error, also known as a 'false positive', is the error of rejecting a null hypothesis when it is actually true. It is an error where the model classifies a healthy company as

TABLE 4: Percentage prediction accuracy of the Stage 1 (fundamental data) and Stage 2 models (fundamental plus market data) by number of years before distress.

\begin{tabular}{|c|c|c|c|c|c|}
\hline Status & $\begin{array}{l}\text { One year before financial } \\
\text { distress }(\%)\end{array}$ & $\begin{array}{c}\text { Two years before financial } \\
\text { distress }(\%)\end{array}$ & $\begin{array}{c}\text { Three years before financial } \\
\text { distress }(\%)\end{array}$ & $\begin{array}{l}\text { Four years before financial } \\
\text { distress }(\%)\end{array}$ & $\begin{array}{c}\text { Five years before financial } \\
\text { distress (\%) }\end{array}$ \\
\hline \multicolumn{6}{|c|}{$\begin{array}{l}\text { Fundamental data Stage } 1 \text { model } \\
\text { Panel A }\end{array}$} \\
\hline Distressed & 63 & 63 & 50 & 100 & 75 \\
\hline Depressed & 7 & 14 & 21 & 14 & 21 \\
\hline Healthy & 100 & 99 & 99 & 100 & 97 \\
\hline Overall percentage & 84 & 84 & 84 & 88 & 85 \\
\hline \multicolumn{6}{|c|}{$\begin{array}{l}\text { Fundamental plus market data Stage } 2 \text { model } \\
\text { Panel B }\end{array}$} \\
\hline Distressed & 100 & 100 & 100 & 100 & 100 \\
\hline Depressed & 14 & 21 & 21 & 29 & 14 \\
\hline Healthy & 99 & 97 & 100 & 100 & 100 \\
\hline Overall percentage & 87 & 87 & 89 & 90 & 88 \\
\hline
\end{tabular}


TABLE 5: Cut-off, classifications and error determination.

\begin{tabular}{|c|c|c|c|c|c|c|c|}
\hline \multirow[t]{2}{*}{ Cut-off } & \multicolumn{2}{|c|}{ Correct prediction } & \multicolumn{2}{|c|}{ Errors } & \multicolumn{3}{|c|}{ Model performance } \\
\hline & $\mathrm{H}$ & D & Type I (\%) & Type II (\%) & H (\%) & $\mathrm{D}(\%)$ & Overall (\%) \\
\hline 0.1 & 92 & 4 & 0 & 50 & 100 & 50 & 96 \\
\hline 0.2 & 92 & 4 & 0 & 50 & 100 & 50 & 96 \\
\hline 0.3 & 91 & 5 & 1 & 37 & 99 & 63 & 96 \\
\hline 0.4 & 91 & 6 & 1 & 25 & 99 & 75 & 97 \\
\hline 0.5 & 91 & 6 & 1 & 25 & 99 & 75 & 97 \\
\hline 0.6 & 91 & 6 & 1 & 25 & 99 & 75 & 97 \\
\hline 0.7 & 90 & 7 & 2 & 12 & 98 & 88 & 97 \\
\hline 0.8 & 89 & 7 & 3 & 12 & 97 & 88 & 96 \\
\hline 0.9 & 86 & 7 & 7 & 12 & 93 & 88 & 93 \\
\hline
\end{tabular}

$\mathrm{H}$, healthy; $\mathrm{D}$, distressed.

distressed. In a group of healthy companies where there is no distressed company, the model says there is a distressed company.

A Type II error, also known as a 'false negative', is the error of not rejecting a null hypothesis when the alternative hypothesis is the true state of nature. This is an error where the model classifies a distressed company as healthy. In a group of distressed companies where there is no healthy company, the model says there is a healthy company.

The abovementioned errors could be very costly for an institutional investor or any financier dealing with large corporations. The rating agencies are also at risk when relying on this model. The magnitude of an error tends to differ at different levels of cut-off points. It then becomes very important to select a cut-off point where the errors are minimised.

Table 5 depicts cut-off points with corresponding error percentages and model performance. The idea is to select a cut-off where the error is minimised.

To enable proper calculation of Types I and II errors, the model results had to be rearranged into a binary format classifying companies as healthy $(\mathrm{H})$ or distressed (D). The first two cut-off points yielded the same results with overall model performance of $96 \%$. The errors at this level were $0 \%$ and $50 \%$ for Types I and II, respectively. A similar result was noticed with cut-off levels $0.4,0.5,0.6$ and 0.7 - the overall model performance at these cut-off points was at $97 \%$, which is a positive result. However, taking a closer look at the first three cut-off levels $(0.4,0.5$ and 0.6$)$, the sum of the two errors was $26 \%(1 \%+25 \%)$. This means that there was a $1 \%$ chance that a healthy company might be classified as distressed. The cost of this would be a loss of interest income that could have been earned from the creditworthy customer. Conversely, there is a $25 \%$ chance that a distressed customer may be approved as healthy, thus the financier losing investment erroneously made to a credit-unworthy customer.

A cut-off point at which the errors were minimal is 0.7. At this level, the model achieved a high percentage overall performance $(97 \%)$, yet the sum of errors was only $14 \%$ $(2 \%+12 \%)$.
The reason why the models fail in the prediction of the depressed companies can only be sought in the definition of depressed companies. In this study two parameters were used in identifying depressed companies, namely earnings before interest and tax, plus income from associated companies as well as net working capital. After applying this criterion (see page 15) to identify depressed companies only 14 companies were identified as depressed, while 78 companies were defined as healthy. As there is a large number of criteria that can be used to identify depressed companies, any other criteria might be able to better identify or classify these companies.

\section{Interpretation of results}

In line with the requirement of a multinomial logistic analysis model, financially distressed companies were assigned a value of 0 , financially depressed companies a value of 1 and financially healthy companies a value of 2 .

In the Stage 1 model a number of fundamental ratios were used, namely WCTA, METD, EBITTA, market value of equity to book value of debt and sales to total assets. From a theoretical point of view, it can be said that when liquidity is low, profitability is low, and when leverage is high, the likelihood of bankruptcy increases. Therefore, the signs for the coefficients, in the regression, of the liquidity and profitability ratios are expected to be negative. On the other hand, for the leverage ratios the expected signs are expected to be positive. Tables 6 and 7 reflect the regression coefficients for the distressed and depressed companies, respectively.

For distressed companies there appears to be a significant negative effect of the liquidity position on working capital to total assets and on profitability, earnings before interest and taxes and turnover to total assets for various years before financial distress. The coefficients 1 year before financial distress reflect higher values than similar values 5 years before financial distress.

Another important observation is that for all years before financial distress similar variables are identified as the most predictive. In the case of the depressed state compared to the healthy state the model also showed a significant negative effect on liquidity (working capital $\div$ total assets) and profitability (earnings before interest and tax $\div$ total assets). 
TABLE 6: The model results reflecting coefficient estimates for distressed companies.

\begin{tabular}{|c|c|c|c|c|c|c|c|}
\hline \multirow[t]{2}{*}{ Code } & \multirow[t]{2}{*}{ Variable } & \multirow[t]{2}{*}{ Statistic } & \multicolumn{5}{|c|}{ Fundamental } \\
\hline & & & $\begin{array}{l}\text { One year before } \\
\text { failure }\end{array}$ & $\begin{array}{l}\text { Two years before } \\
\text { failure }\end{array}$ & $\begin{array}{l}\text { Three years before } \\
\text { failure }\end{array}$ & $\begin{array}{l}\text { Four years before } \\
\text { failure }\end{array}$ & $\begin{array}{l}\text { Five years before } \\
\text { failure }\end{array}$ \\
\hline \multirow[t]{2}{*}{$\mathrm{x} 1$} & EBITTA & Coeff & -51.115 & -11.897 & -0.845 & -1109.00 & -27.759 \\
\hline & & Sig. & 0.005 & 0.007 & 0.635 & - & 0.02 \\
\hline \multirow[t]{2}{*}{$\mathrm{x} 2$} & TDTA & Coeff & - & - & - & - & - \\
\hline & & Sig. & - & - & - & - & - \\
\hline \multirow[t]{2}{*}{$\mathrm{x} 3$} & METD & Coeff & - & - & - & - & - \\
\hline & & Sig. & - & - & - & - & - \\
\hline \multirow[t]{2}{*}{$\mathrm{X} 4$} & TOTA & Coeff & -6.616 & -1.857 & -1.398 & -17.313 & -1.792 \\
\hline & & Sig. & 0.022 & 0.136 & 0.100 & 0.995 & 0.243 \\
\hline \multirow[t]{2}{*}{ X5 } & WCTA & Coeff & -9.242 & -12.725 & -10.132 & -567.148 & -2.812 \\
\hline & & Sig. & 0.016 & 0.000 & 0.001 & 0.925 & 0.472 \\
\hline
\end{tabular}

Note: All coefficients are statistically significant between 0.05 and 0.10 .

Coeff, coefficient of the variable in the fitted model; Sig., significance level ( $p$-value); WCTA, working capital over total assets; TDTA, total debt $\div$ total assets; EBITTA, earnings before interest and tax $\div$ total assets; TOTA, turnover $\div$ total assets; METD, market capitalisation $\div$ total debt.

TABLE 7: The model results reflecting the coefficient estimates for depressed companies.

\begin{tabular}{|c|c|c|c|c|c|c|c|}
\hline \multirow[t]{2}{*}{ Code } & \multirow[t]{2}{*}{ Variable } & \multirow[t]{2}{*}{ Statistic } & \multicolumn{5}{|c|}{ Fundamental } \\
\hline & & & $\begin{array}{c}\text { One year before } \\
\text { failure }\end{array}$ & $\begin{array}{c}\text { Two years before } \\
\text { failure }\end{array}$ & $\begin{array}{c}\text { Three years before } \\
\text { failure }\end{array}$ & $\begin{array}{l}\text { Four years before } \\
\text { failure }\end{array}$ & $\begin{array}{c}\text { Five years before } \\
\text { failure }\end{array}$ \\
\hline $\mathrm{X} 1$ & EBITTA & Coeff & -5.385 & -9.745 & -0.724 & -4.314 & 3.626 \\
\hline \multirow[t]{2}{*}{$\mathrm{X} 2$} & TDTA & Coeff & - & - & - & - & - \\
\hline & & Sig. & - & - & - & - & - \\
\hline X3 & METD & Coeff & - & - & - & - & - \\
\hline \multirow[t]{2}{*}{ X4 } & TOTA & Coeff & -0.306 & 0.045 & 0.071 & -0.049 & -0.046 \\
\hline & & Sig. & 0.467 & 0.909 & 0.844 & 0.896 & 0.883 \\
\hline \multirow[t]{2}{*}{ x5 } & WCTA & Coeff & -6.954 & -6.864 & -5.342 & -7.385 & -5.594 \\
\hline & & Sig. & 0.003 & 0.002 & 0.003 & 0.003 & 0.011 \\
\hline
\end{tabular}

Note: All coefficients are statistically significant at 0.05 .

Coeff, coefficient of the variable in the fitted model; Sig., significance level ( $p$-value); WCTA, working capital over total assets; TDTA, total debt $\div$ total assets; EBITTA, earnings before interest and tax $\div$ total assets; TOTA, turnover $\div$ total assets; METD, market capitalisation $\div$ total debt.

The latter ratio was also found to be of great significance in distress prediction by Bellovary et al. (2007). The working capital $\div$ total assets ratio appears to be the most predictive variable for all years before financial distress (which is in line with Altman 1968). This is the case for both distressed and depressed companies.

From the above it can be inferred that it is important for companies to preserve liquidity and to maintain profitability. Regarding the preservation of healthy levels of liquidity, management needs to ensure that effective working capital management strategies are always in place. This observation is self-evident as, without the proper management of working capital, companies may find themselves unable to meet short-term obligations. More specifically, management should constantly (on at least a monthly basis) monitor their ratio of working capital to total assets as well as the composition of working capital and therefore the ratio of accounts receivable, cash and inventory not only to each other but to accounts payable. This should be done while keeping in mind the type of industry within which a firm operates (e.g. management of firms in the retail industry should be more sensitive to working capital variations relative to the manufacturing industry, the latter relying more on non-current assets for their survival). In summary, management should acquaint themselves with the science of managing working capital, as a number of past studies have proved the relationship between working capital and profitability (Ajibolade \& Sankay 2013; Baňos-Caballero, Garcĩa-Teruel \& Martĩnez-Solano 2012; Enqvist, Graham \& Nikkinen 2014).

Also, while the company may appear healthy, in that it has not yet filed for financial distress, it remains important that company managers maintain profitable operations. In this regard, efforts to implement product costing and monitoring systems can improve profitability. A reliable product ordering system can enhance the relationship between the purchase price, profit markup and selling price of individual items, thereby optimising profitability.

Research question 1 asked whether the Stage 1 model (which consisted only of fundamental ratios) can accurately predict the financial distress of companies. The answer is affirmative and Table 4 confirmed that the Stage 1 approach can accurately predict financial distress, with an average percentage prediction accuracy of $85 \%$ for the 5 years before financial distress.

Research question 2 asked whether adding market-based variables can improve the prediction accuracy of the model. Table 5 confirmed the enhancement after market-based data was added. The average percentage prediction accuracy increased to $88 \%$ for the 5 years before financial distress. 
Research question 3 asked whether adding macroeconomic variables can improve the prediction accuracy of the model. Unfortunately, here the answer is negative; Stage 3 did not increase the predictive accuracy of the model. Therefore, the implications for management of the result of the present study is that fundamental data alone (ratios from the financial statements, such as working capital $\div$ total assets and earnings before tax $\div$ total assets) is not enough to predict financial distress; market-based data and ratios (the $\mathrm{P} / \mathrm{E}$ ratio and share price movement) should be added and incorporated to enhance the prediction and prevention of financial distress.

\section{Conclusion}

Financial distress prediction has for many decades formed the basis of extensive research. Financial distress prediction models have evolved markedly over the last number of decades as the importance and implications of financial distress has become more evident. The goal of the present study was to develop and test a financial distress prediction model that used logistic regression in a three-stage model to determine indicators of financial distress in companies listed on the JSE. In Stage 1 only fundamental ratios were used as variables; in Stage 2 market variables were added; and in Stage 3 macroeconomic variables were added. Empirical results indicated that although the Stage 2 model had a prediction accuracy of between $87 \%$ and $90 \%$, the addition of economic variables in Stage 3 did not improve the predictive powers of the model. While liquidity (measured by working capital to total assets) played the most important role, profitability (measured by earnings before interest and taxes to total assets) and turnover to total assets were also important.

The contribution of this study is to emphasise to management the importance of liquidity, profitability and turnover of assets in predicting financial distress. Furthermore, there is a clear need to consider adding market-based data to the model to improve the overall prediction results. This study adds to the existing literature by developing a methodology that can more accurately predict the depressed financial state of companies 1-5 years before financial distress, which provides an opportunity for management to implement timely turnaround strategies.

Further studies could be conducted to develop and search for new or other financial ratios to be used in predicting financial distress instead of applying ratios that were found to be successful in previous studies. Regarding the statistical methodology, the South African academic community still needs to explore the performance of neural networks in predicting financial distress. While this methodology is widely used globally, not enough research is found in South Africa in this regard.

\section{Acknowledgements Competing interests}

The authors declare that they have no financial or personal relationships which may have inappropriately influenced them in writing this article.

\section{Authors' contributions}

This manuscript is based on S.W.S.'s PhD thesis, submitted at the University of Pretoria. L.M.B. was the supervisor while J.H.H. and H.P.W. were co-supervisors. This manuscript was originally written by S.W.S. Then L.M.B., J.H.H. and H.P.W. contributed to the review and in-depth review of the manuscript.

\section{References}

Ahmadi, A.P.S., Soleimani, B., Vaghfi, S.H. \& Salimi, M.B., 2012, 'Corporate bankruptcy prediction using a logit model: Evidence from listed companies from Iran', World Applied Science Journal 17(9), 1143-1148.

Ajibolade, S.O. \& Sankay, O.C., 2013, 'Working capital management and financing decision: Synergetic effect on corporate profitability', International Journal of Management, Economics and Social Sciences 2(4), 233-251. https://doi.org/ $10.2139 /$ ssrn. 2367990

Ala'raj, M. \& Abbod, M., 2016, 'Classifiers consensus system approach for credit scoring', Knowledge-Based Systems 104, 89-105. https://doi.org/10.1016/j.knosys. 2016.04.013

Altman, E.I., 1968, 'Financial ratios, discriminant analysis and the prediction of corporate bankruptcy', Journal of Finance 23(4), 589-609. https://doi.org/ 10.1111/j.1540-6261.1968.tb00843.x

Altman, E.I., Haldeman, G. \& Narayanan, P., 1977, 'Zeta analysis: A new model to identify bankruptcy risk of corporations', Journal of Banking and Finance 1(1), 29-54. https://doi.org/10.1016/0378-4266(77)90017-6

Altman, E.I., Iwanicz-Drozdowska, M., Laitinen, E.K. \& Suvas, A., 2017, 'Financial distress prediction in an international context: A review and empirical analysis of Altman's Z-score model', Journal of International Financial Management \& Accounting 28(2), 131-171. https://doi.org/10.1111/jifm.12053

Åstebro, T. \& Winter, J.K., 2012, 'More than a dummy: The probability of failure, survival and acquisition of firms in financial distress', European Management Review 9(1), 1-17. https://doi.org/10.1111/j.1740-4762.2011.01024.x

Aydin, A.D. \& Cavdar, S.C., 2015, 'Two different points of view through artificial intelligence and vector autoregressive models for ex post and ex ante forecasting', Journal of Computational Intelligence and Neuroscience 2015, 409361, 1-11. https://doi.org/10.1155/2015/409361

Baňos-Caballero, S., Garcĩa-Teruel, P.J. \& Martĩnez-Solano, P., 2012, 'Working capital requirement financing and SMEs performance', Paper Delivered at the Nineteenth Annual Conference of the Multinational Finance Society held in Krakow, Poland, 24-27th June.

Beaver, W.H., 1966, 'Financial ratios as predictors of failure', Journal of Accounting Research 4(3), 71-111. https://doi.org/10.2307/2490171

Bellovary, J., Giacomino, D. \& Akers, M., 2007, 'A review of bankruptcy prediction studies: 1930-present', Journal of Financial Education 33(Winter), 1-42.

Bennett, S., 1983, 'Log-logistic regression models for survival data', Applied Statistics 32(2), 165-171. https://doi.org/10.2307/2347295

Cao, Y. \& Chen, X., 2012, 'An agent-based simulation model of enterprises financial distress for the enterprise of different life cycle stages', Journal of Simulation Modelling Practice and Theory 20(1), 70-88. https://doi.org/10.1016/j.simpat. 2011.08.008

Carmichael, D.R., 1978, The auditor's reporting obligation: The meaning and implementation of the fourth standard of reporting, 2nd edn., American Institute of Certified Public Accountants, New York.

Cassim, Z., 2015, 'Predicting financial distress of JSE-listed companies using Bayesian networks', Unpublished Masters dissertation, University of Cape Town, Cape Town.

Chadha, P., 2016, 'Exploring the financial performance of the listed companies in Kuwait Stock Exchange using Altman's Z-score model', International Journal of Kuwait Stock Exchange using Altman's Z-score model, International Journal of Economics and

Cleofas-Sanchez, L., Garcia, V., Marques, A.I. \& Sanchez, J.S., 2016, 'Financial distress prediction using the hybrid associative memory', Applied Soft Computing 44, 144-152. https://doi.org/10.1016/j.asoc.2016.04.005

Dimitras, A.I., Zanakis, S.H. \& Zopounidis, C., 1996, 'A survey of business failures with an emphasis on prediction methods and industrial applications', Journal of Operational Research 90(3), 487-513. https://doi.org/10.1016/0377-2217(95) 00070-4

Doumpos, M. \& Zopounidis, C., 1999, 'Business failure prediction using the UTADIS multicriteria analysis method', Journal of Operational Research Society 50(11), 1138-1148. https://doi.org/10.1057/palgrave.jors.2600818

Enqvist, J., Graham, M. \& Nikkinen, J., 2014, 'The impact of working capital management on firm profitability in different business cycles: Evidence from Finland', Research in International Business and Finance 32, 36-49. https://doi. org/10.1016/j.ribaf.2014.03.005

Fitzpatrick, P.J., 1932, 'A comparison of the ratios of successful industrial enterprises with those of failed companies', The Certified Public Accountant, October, 598-605.

Gloubos, G. \& Grammatikos, T., 1988, 'The success of bankruptcy prediction models in Greece', Studies in Banking and Finance 7, 37-46. 
Hand, D.J. \& Henley, W.E., 1997, 'Statistical classification methods in consumer credit scoring: A review' Journal of the Royal Statistical Society 160(3), 523-541. https:// scoring: A review', Journal of the Royal Statisticd
doi.org/10.1111/j.1467-985X.1997.00078.x

Holtzhausen, G.T.D., 2011, 'Modelling business turnaround strategies using verifier determinants from early warning signs theory', Unpublished PhD thesis, University of Pretoria, Pretoria.

Jones, S. \& Hensher, D.A., 2007, 'Modelling corporate failure: A multinomial nested logit analysis for unordered outcomes', The British Accounting Review 39(1), 89-107. https://doi.org/10.1016/j.bar.2006.12.003

Keasey, K. \& Watson, R., 1987, 'Non-financial symptoms and the prediction of small company failure: A test of Argenti's hypotheses', Journal of Business Finance and Accounting 14(3), 335-354. https://doi.org/10.1111/j.1468-5957.1987.tb00099.x

Laitinen, E.K. \& Laitinen, T., 2000, 'Bankruptcy prediction: Application of the Taylor's expansion in logistic regression', International Review of Financial Analysis 9 327-349. https://doi.org/10.1016/S1057-5219(00)00039-9

Li, H. \& Sun, J., 2011, 'Empirical research of hybridizing principal component analysis with multivariate discriminant analysis and logistic regression for business failure prediction', Expert Systems and Applications 38(5), 6244-6253. https://doi.org/ 10.1016/j.eswa.2010.11.043

López Iturriaga, F.J. \& Sanz, I.P., 2015, 'Bankruptcy visualization and prediction using neural networks: A study of US commercial banks', Expert Systems with Applications 42, 2857-2869. https://doi.org/10.1016/j.eswa.2014.11.025

Lussier, R.N., 1995, 'A nonfinancial business success versus failure prediction model for young firms', Journal of Small Business Management 33(1), 8-20.

Manzaneque, M., Priego, A.M. \& Merino, E., 2016, 'Corporate governance effect on financial distress likelihood: Evidence from Spain', Spanish Accounting Review 19(1), 111-121. https://doi.org/10.1016/j.rcsar.2015.04.001

McFadden, D., 1974, 'Conditional logit analysis of qualitative choice behaviour', in P. Zarembka (ed.), Frontiers in econometrics, pp. 105-142, Academic Press, New York.

Moses, D. \& Liao, S.S., 1987, 'On developing models for failure prediction', Journal of Commercial Bank Lending 69, 27-38.

Muller, G.H., Steyn-Bruwer, B.W. \& Hamman, W.D., 2009, 'Predicting financial distress of companies listed on the JSE - A comparison of techniques', South African Journal of Business Management 40(1), 21-32.

Odom, M. \& Sharda, R., 1990, 'A neural network model for bankruptcy prediction', in Proceedings of the IEEE International Joint Conference on Neural Networks, IEEE Press, San Diego, CA, pp. 163-168.
Ohlson, J.A., 1980, 'Financial ratios and the probabilistic prediction of bankruptcy', Journal of Accounting Research 18(1), 109-131. https://doi.org/10.2307/2490395

Peng, C. J., Lee, K.L. \& Ingersoll, G.M., 2002, 'An introduction to logistic regression analysis and reporting', The Journal of Educational Research 96(1), 3-14. https:// doi.org/10.1080/00220670209598786

Rowlings, D., 2016, 'A corporate failure prediction model for non-financial South African corporates incorporating best practices used by the credit industry', Unpublished Masters dissertation, University of Cape Town, Cape Town.

Shah, N., 2014, 'Developing financial distress prediction models using cutting edge recursive partitioning techniques: A study of Australian mining performance', Review of Integrative Business and Economics Research 3(2), 103-143.

Tam, K.Y. \& Kiang, M.Y., 1992, 'Managerial applications of neural networks: The case of bank failure predictions', Management Science 38(7), 926-947. https://doi.org/ 10.1287/mnsc.38.7.926

Tamari, M., 1966, 'Financial ratios as a means of forecasting bankruptcy', Management International Review 6(4), 15-21.

Tinoco, M.H. \& Wilson, N., 2013, 'Financial distress and bankruptcy prediction among listed companies using accounting, market and macroeconomic variables', International Review of Financial Analysis 30, 394-419. https://doi.org/10.1016/j. irfa.2013.02.013

Tseng, F. \& Lin, L., 2005, 'A quadratic interval model for forecasting bankruptcy', Omega 33(1), 85-91.

Van der Colff, F. \& Vermaak, F., 2015, 'Predicting financial distress using financial and non-financial variables', Journal of Economic and Financial Sciences 8(1), 243-260. https://doi.org/10.1016/j.omega.2004.04.002

Wang, Y. \& Campbell, M., 2010, 'Business failure prediction for publicly listed companies in China', Journal of Business and Management 16(1), 75-88.

Yim, J. \& Mitchell, H., 2005, 'A comparison of corporate distress prediction models in Brazil: Hybrid neural networks, logit models and discriminant analysis', Nova Economia 15(1), 73-93.

Zavgren, C., 1983, 'The prediction of corporate failure: The state of the art', Journal of Accounting Literature 2, 1-35.

Zavgren, C., 1985, 'Assessing the vulnerability to failure of American industrial firms: A logistic analysis', Journal of Business Finance and Accounting 12(1), 19-45. https:// doi.org/10.1111/j.1468-5957.1985.tb00077.x

Zmijewski, M.E., 1984 'Methodological issues related to the estimation of financial distress prediction models', Journal of Accounting Research 22, 59-82. https:// doi.org/10.2307/2490859 